\title{
Atrial Natriuretic Peptide Receptor 2
}

National Cancer Institute

\section{Source}

National Cancer Institute. Atrial Natriuretic Peptide Receptor 2. NCI Thesaurus. Code C33978.

Atrial natriuretic peptide receptor 2 (1047 aa, $117 \mathrm{kDa}$ ) is encoded by the human NPR2 gene. This protein plays a role in peptide hormone binding and guanylyl cyclase activity. 